\title{
Effect of topical atenolol on intraocular pressure
}

\author{
KARIN WETTRELL AND MAURIZIO PANDOLFI \\ From the Department of Ophthalmology, Hospital of Malmö, University of Lund, Sweden
}

SUMMARY Placebo and topical atenolol (Tenormin), a selective $\beta_{1}$-adrenergic blocking substance with no intrinsic sympathomimetic or membrane-stabilising properties, were tested in 16 patients with ocular hypertension in a double-blind cross-over trial. Three different concentrations of atenolol $(1,2$, and $4 \%)$ were investigated. After a single instillation there was a statistically significant fall in mean intraocular pressure (IOP) with all the concentrations after one hour, with a maximum after two to three hours. The effect had passed off after seven hours. In multiple-dose studies with applications three times a day for seven days there was a statistically significant fall in the mean IOP on the first day of treatment (all three concentrations), which persisted throughout the week. In the single-dose study only a slight dose-dependence was observed. This could not be confirmed in the multiple-dose trial. Pupil size, corneal sensitivity, systemic blood pressure, and heart rate were unaffected. No side effects were noted. Thus topically applied atenolol lowers IOP in patients with ocular hypertension and may be clinically useful.

Propranolol, a $\beta$-adrenergic blocking agent which inhibits both $\beta_{1}$ receptors (cardiac receptors) and $\beta_{2}$ receptors (broncho- and vasodilatating receptors), has an ocular hypotensive action when given systemically (Phillips et al., 1967; Coté and Drance, 1968; Vale and Phillips, 1970; Öhrström, 1973; Pandolfi and Öhrström, 1974; Sharaf et al., 1974; Wettrell and Pandolfi, 1975; Borthne, 1976; Wettrell and Pandolfi, 1976; Wettrell et al., 1977). Practolol (a selective $\beta_{1}$ antagonist but with some intrinsic sympathomimetic activity) acts in the same way (Hagedorn and Tjoa, 1974; Wettrell and Pandolfi, 1975; Wettrell et al., 1977). A fall in ocular tension has also been reported after topical application of propranolol and practolol (Musini et al., 1971; Bietti, 1972; Vale et al., 1972; Vale and Phillips, 1973). The mode of action is unknown but in the case of propranolol has been ascribed to secondary effects such as membrane stabilisation (Musini et al., 1971).

Recently another beta-blocking compound, atenolol (Tenormin) (Fig. 1), a selective inhibitor of $\beta_{1}$ receptors, has been introduced. Unlike practolol and propranolol it has neither intrinsic activity nor membrane-stabilising properties (Barrett et al., 1973), but when given by mouth it lowers intraocular pressure (IOP) (Elliot et al., 1975; Wettrell and Pandolfi, 1975; Wettrell et al., 1977). There have been no re-

Address for reprints: Karin Wettrell, MD, Department of Ophthalmology, Hospital of Malmö, University of Lund, 21401 Malmö, Sweden
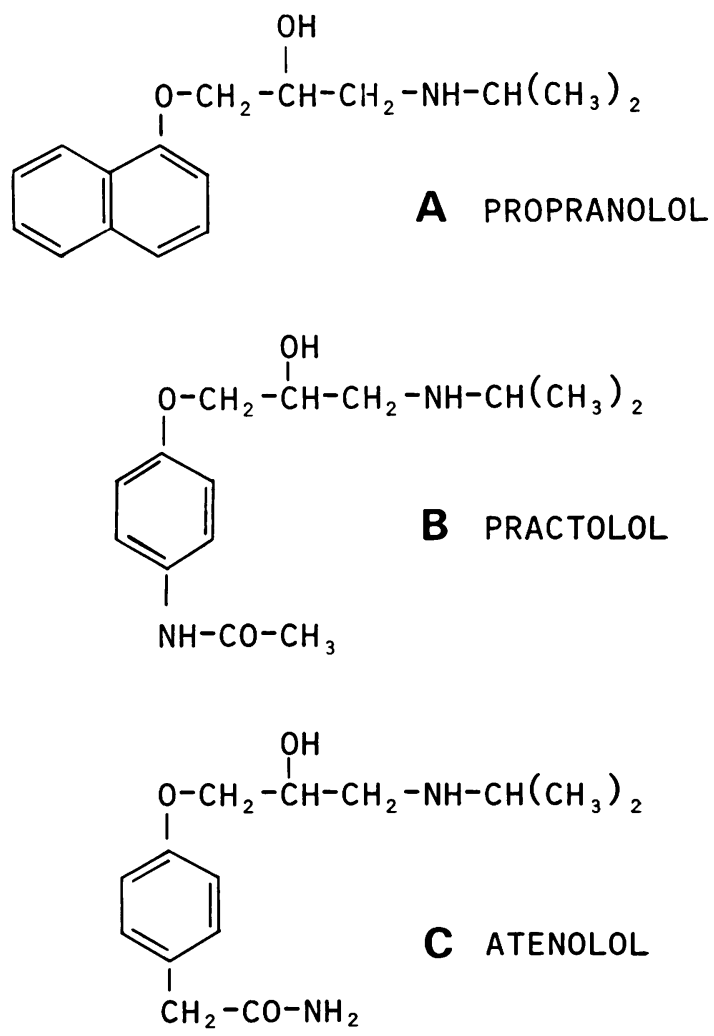

Fig. 1 Structural formulae of beta-adrenergic inhibitors propranolol, practolol, atenolol 
ports on the local use of atenolol, and the aim of the present study was to elucidate if topically administered atenolol could reduce IOP in man, and, if so, to investigate the time-course and dose-response relationship.

\section{Patients and drugs}

The clinical material consisted of 16 patients (11 females and 5 males) of various ages (mean age 61, range 32 to 73 ). The subjects had an IOP $\geqslant 22 \mathrm{mmHg}$ but normal visual fields and optic discs. One fellow eye in the single dose study had an untreated IOP of about $20 \mathrm{mmHg}$ but was included in the trial. Some of the patients (11) were previously treated with pilocarpine, which was withdrawn at least 48 hours prior to the study. One patient did not complete the last treatment period. The subjects were not receiving systemic adrenergic drugs during the study. There was no history of asthma, bronchospasm, or other disorders contraindicating treatment with adrenergic beta-blockers. Before the study began a cardiovascular examination was made and ECG taken to ascertain suitability for the trial.

The eyedrops were prepared by ICI Pharmaceuticals and contained atenolol in concentrations 1,2 , and $4 \%$ respectively. Benzalkonium chloride $(0.02 \% \mathrm{v} / \mathrm{v})$ was used as a preservative and the $\mathrm{pH}$ was adjusted to $6 \cdot 0$. The placebo eyedrop had the same composition except for the absence of atenolol.

\section{Methods}

The trial was performed in a double-blind cross-over manner in which each person received the three concentrations of atenolol and placebo. The order of administration of the formulations was randomised and each concentration was tested with a drug-free interval of at least $\mathbf{4 8}$ hours.

\section{Single-dose study}

Eight patients (16 eyes) participated in the trial. One hour before and $0 \cdot 5,1,1 \cdot 5,2,3,4$, and $7 \mathrm{~h}$ after instillation of one drop of atenolol or placebo in both eyes IOP, pupil size, systemic blood pressure, and heart rate were recorded. IOP was measured with a Goldmann applanation tonometer, which was calibrated daily. Before tonometry 1 to 2 drops of Fluress (Pharmacia AB, Uppsala, Sweden), a combination of oxibuprocaine hydrochloride and sodium fluorescein, were instilled into the conjunctival sac. The diameter of the pupil was measured in the Goldmann perimeter, while blood pressure and heart rate were recorded after five minutes' rest in the supine position.

\section{Multiple-dose study}

Ten patients (20 eyes) were selected for the study. Two of them (one male and one female) also took part in the single-dose study. Each patient was instructed to instil 1 to 2 drops atenolol or placebo in both eyes three times daily at 7 a.m., noon, and 7 p.m. for seven days. Before the trial the baseline IOP was measured with a Goldmann applanation tonometer at 8 a.m., noon, and 4 p.m. At noon the systemic blood pressure and heart rate were measured in the supine position. Corneal sensitivity was tested with Cochet and Bonnet's aesthesiometer (Cochet and Bonnet, 1960). These measurements were repeated on the first, fourth, and seventh day of treatment. On the seventh day IOP was also recorded at 8 a.m. and 4 p.m.

Statistical analysis of the results was made by Student's $t$ test for paired data. IOP during treatment with active substance and placebo were compared.

\section{Results}

One hour after the instillation of atenolol a statistically significant fall in mean IOP was observed with all the concentrations tested. This fall was maximum after two to three hours and had disappeared after seven hours (Table 1, Fig. 2). The mean maximum fall after application of 1,2 , and $4 \%$ atenolol was

Table 1 Mean ( \pm SEM) variation in IOP ( $\mathrm{mmHg}$ ) at intervals during a seven-hour period after a single instillation of different concentrations of atenolol compared with results with placebo (see Fig. 2). Statistical significances in parentheses

\begin{tabular}{|c|c|c|c|c|c|c|c|c|}
\hline \multirow{2}{*}{$\begin{array}{l}\text { Atenolol } \\
\text { concentration } \\
(\%)\end{array}$} & \multirow{2}{*}{$\begin{array}{l}\text { No. of } \\
\text { eyes }\end{array}$} & \multicolumn{7}{|c|}{ Mean IOP variation $( \pm S E M)$ at hour: } \\
\hline & & 0.5 & 1.0 & $1 \cdot 5$ & $2 \cdot 0$ & 3.0 & $4 \cdot 0$ & $7 \cdot 0$ \\
\hline 1 & 16 & $\begin{array}{c}1 \cdot 1 \\
\pm 0.42 \\
(\mathrm{P}<0.02)\end{array}$ & $\begin{array}{l}-3.1 \\
\pm 1 \cdot 20 \\
(\mathrm{P}<0.05)\end{array}$ & $\begin{array}{l}-3.9 \\
\pm 1.29 \\
(P<0.01)\end{array}$ & $\begin{array}{l}-4.0 \\
\pm 0.85 \\
(P<0.001)\end{array}$ & $\begin{array}{l}-4.9 \\
\pm 0.95 \\
(\mathrm{P}<0.001)\end{array}$ & $\begin{array}{l}-3.4 \\
\pm 1.21 \\
(\mathrm{P}<0.02)\end{array}$ & $\begin{array}{l}-0.3 \\
\pm 0.62 \\
\text { (NS) }\end{array}$ \\
\hline 2 & 16 & $\begin{array}{l}-0.4 \\
\pm 0.91 \\
\text { (NS) }\end{array}$ & $\begin{array}{l}-3.7 \\
\pm 0.71 \\
(\mathrm{P}<0.001)\end{array}$ & $\begin{array}{l}-5.1 \\
+0.66 \\
(P<0.001)\end{array}$ & $\begin{array}{l}-6.1 \\
\pm 0.89 \\
(P<0.001)\end{array}$ & $\begin{array}{l}-5.9 \\
\pm 0.79 \\
(\mathbf{P}<0.001)\end{array}$ & $\begin{array}{l}-4.6 \\
\pm 0.94 \\
(P<0.001)\end{array}$ & $\begin{array}{l}-0.2 \\
\pm 0.81 \\
\text { (NS) }\end{array}$ \\
\hline 4 & 16 & $\begin{array}{l}0 \\
\text { (NS) }\end{array}$ & $\begin{array}{l}-4.9 \\
\pm 0.81 \\
(\mathrm{P}<0.001)\end{array}$ & $\begin{array}{l}-6.0 \\
\pm 1.00 \\
(P<0.001)\end{array}$ & $\begin{array}{l}-6.3 \\
\pm 0.88 \\
(P<0.001)\end{array}$ & $\begin{array}{l}-6.3 \\
\pm 0.76 \\
(P<0.001)\end{array}$ & $\begin{array}{l}-5.7 \\
\pm 1.04 \\
(P<0.001)\end{array}$ & $\begin{array}{l}-0.7 \\
\perp 0.93 \\
\text { (NS) }\end{array}$ \\
\hline
\end{tabular}


$10 P$

$\mathrm{mm} \mathrm{Hg}$
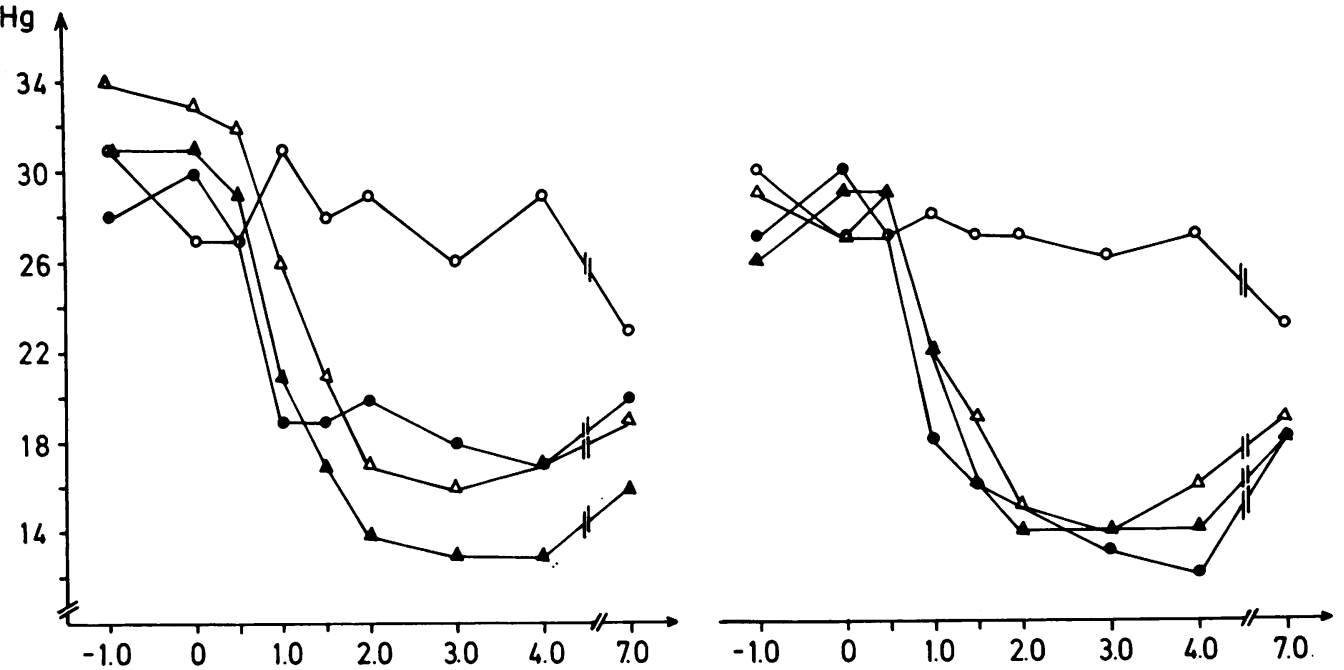

Fig. 2 Duration of IOP response of one patient after treatment with placebo and different concentrations of

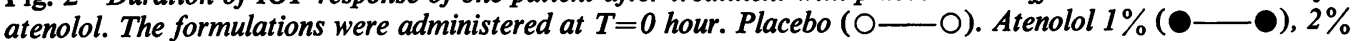
$(\triangle \longrightarrow \triangle), 4 \%(\triangle-\Delta) . R E=$ right eye, $L E=$ left eye

$4 \cdot 9,6 \cdot 1$, and $6.3 \mathrm{mmHg}$ respectively. Only a slight dose-dependence was noted.

No changes in pupil size, systemic blood pressure, or heart rate were apparent.

On the first day of treatment there was a distinct, statistically significant fall in mean IOP at noon with all concentrations of atenolol (Table 2). The mean fall was $2 \cdot 4,2 \cdot 6$, and $3 \cdot 4 \mathrm{mmHg}$ for 1,2 , and $4 \%$ concentrations respectively. The fall persisted and was statistically significant throughout the week, although the response tended to diminish at the end of the period (Table 2). The fall did not seem to be dose-dependent. A slight placebo effect was noted (Table 3, Fig. 4). Corneal sensitivity, systemic blood pressure, and heart rate were unaffected. The patients did not report any local or general side effects, and there were no signs of intolerance to the drug.

\section{Discussion}

This study shows that atenolol lowers IOP when applied topically in patients with ocular hypertension, as others have previously reported that it does when taken by mouth (Elliot et al., 1975; Wettrell and Pandolfi, 1975; Wettrell et al., 1977). Elliot et al. (1975) reported that IOP fell one hour after a single oral dose of $50 \mathrm{mg}$ atenolol with a maximum fall after five hours.

We found that IOP fell one hour after topical application of atenolol and that the fall reached a
Table 2 Mean $( \pm S E M)$ variation in IOP $(\mathrm{mmHg})$ at noon on days 1,4 , and 7 of one week's treatment with atenolol in different concentrations compared with results with placebo (Fig. 3)

\begin{tabular}{|c|c|c|c|c|}
\hline \multirow{2}{*}{$\begin{array}{l}\text { Atenolol } \\
\text { concentration } \\
(\%)\end{array}$} & \multirow{2}{*}{$\begin{array}{l}\text { No. of } \\
\text { eyes }\end{array}$} & \multicolumn{3}{|c|}{ Mean IOP variation $( \pm S E M)$ on day: } \\
\hline & & 1 & 4 & 7 \\
\hline 1 & 20 & $\begin{array}{l}-2.4 \pm 0.64 \\
(P<0.01)\end{array}$ & $\begin{array}{l}-3 \cdot 0 \pm 0.66 \\
T<0.001)\end{array}$ & $\begin{array}{l}-1 \cdot 7 \pm 0.64 \\
(P<0.02)\end{array}$ \\
\hline 2 & 20 & $\begin{array}{l}-2.6 \pm 0.51 \\
(P<0.001)\end{array}$ & $\begin{array}{l}-1 \cdot 8 \pm 0.66 \\
(P<0.02)\end{array}$ & $\begin{array}{l}-2 \cdot 0 \pm 0.29 \\
(P<0.001)\end{array}$ \\
\hline 4 & 18 & $\begin{array}{l}-3.4 \pm 0.63 \\
(P<0.001)\end{array}$ & $\begin{array}{l}-3.5 \pm 0.79 * \\
(\mathrm{P}<0.001)\end{array}$ & $\begin{array}{l}-2.1 \pm 0.35 \\
(P<0.001)\end{array}$ \\
\hline
\end{tabular}

*16 eyes

Table 3 Mean ( \pm SEM) IOP ( $\mathrm{mmHg}$ ) after 7 days' treatment with placebo and atenolol in different concentrations (active substance compared with placebo)

\begin{tabular}{|c|c|c|c|c|}
\hline & \multirow{2}{*}{$\begin{array}{l}\text { No. of } \\
\text { eyes }\end{array}$} & \multicolumn{3}{|c|}{$I O P( \pm S E M)$ at } \\
\hline & & $8 \mathrm{am}$ & Noon & $4 p m$ \\
\hline Untreated & 20 & $25 \cdot 9 \pm 0.80$ & $24 \cdot 0 \pm 0 \cdot 61$ & $23 \cdot 0 \pm 0 \cdot 73$ \\
\hline Placebo & 20 & $24 \cdot 9 \pm 0.87$ & $\begin{array}{l}22.8 \pm 0.66 \\
(P<0.05)\end{array}$ & $22 \cdot 1 \pm 0 \cdot 77$ \\
\hline $1 \%$ Atenolol & 20 & $\begin{array}{l}22.2 \pm 0.60 \\
(P<0.01)\end{array}$ & $\begin{array}{l}21 \cdot 2 \pm 0.88 \\
(P<0.05)\end{array}$ & $20 \cdot 7 \pm 0.56$ \\
\hline $2 \%$ Atenolol & 20 & $\begin{array}{l}22.4 \pm 0.57 \\
(P<0.001)\end{array}$ & $\begin{array}{l}20.8 \pm 0.54 \\
(P<0.001)\end{array}$ & $21.4 \pm 0.73$ \\
\hline $4 \%$ Atenolol & 18 & $\begin{array}{l}23.3 \pm 0.76 \\
(P<0.05)\end{array}$ & $\begin{array}{l}20.6 \pm 0.50 \\
(P<0.001)\end{array}$ & $\begin{array}{l}20.8 \pm 0.61 \\
(P<0.01)\end{array}$ \\
\hline
\end{tabular}


IOP

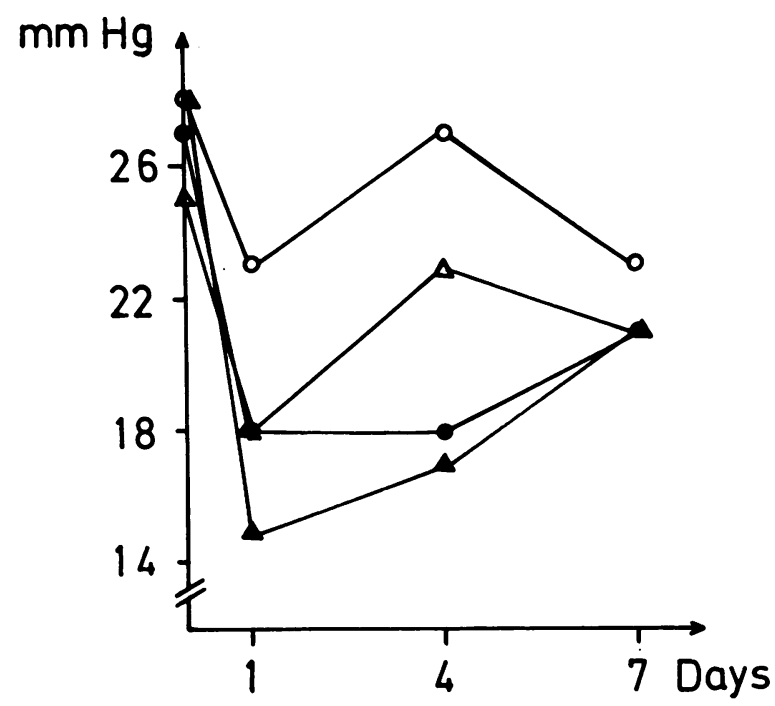

LE

Fig. 3 IOP in one patient during seven days' treatment with placebo and different concentrations of atenolol three

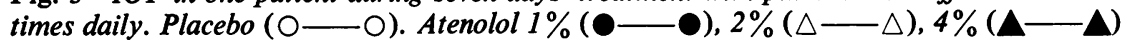
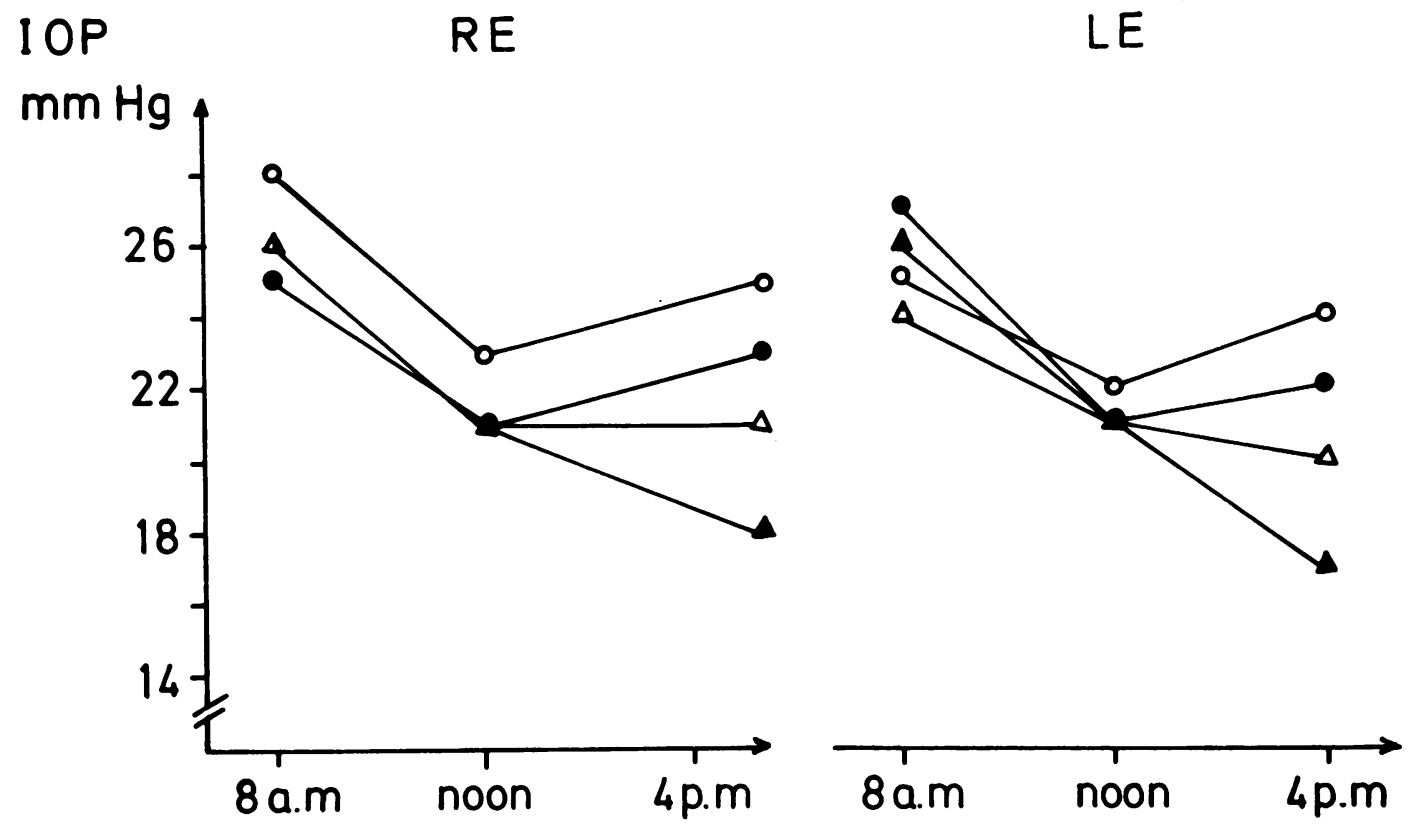

Fig. 4 Diurnal IOP in one patient after seven days' treatment with placebo and different concentrations of atenolol three times daily. Placebo $(\mathrm{O}-\mathrm{O})$. Atenolol $1 \%(\mathrm{-}), 2 \%(\triangle-\triangle), 4 \%(\triangle-\triangle)$

maximum after two to three hours. A similar time course has been described with other topically administered $\beta$ antagonists such as propranolol, practolol, pindolol, and oxprenolol (Vale et al., 1972; Vale and Phillips, 1973; Bonomi and Steindler,
1975; Bucci, 1976), but these substances have caused side effects such as hyperaemia of the conjunctiva and discomfort.

Unlike propranolol, atenolol has no membrane stabilising properties. Thus it had no effect on 
corneal sensitivity in our patients. This disproves the assumption that it is the anaesthetic action that causes the fall in IOP (Musini et al., 1971). Its lack of anaesthetic properties and the absence of adverse reactions seem to make atenolol more suitable for local application than other beta-blockers. Atenolol is a selective $\beta_{1}$ antagonist without intrinsic activity. This suggests that its action in reducing IOP must in some way be mediated by the inhibition of the $\beta_{1}$ receptors in the eye. It remains to be seen whether this inhibition causes an increase in outflow facility or impairs the production of aqueous humour.

In our multiple-dose study the fall in IOP was less than the maximum effect in the single-dose trial. Nevertheless, in the multiple-dose study IOP was measured at noon-that is, about five hours after the first application of atenolol and immediately before the second application. Therefore, judging from the single-dose study, the maximum effect had already passed and the IOP was recorded in the recovery phase.

In the multiple-dose study a tendency to tachyphylaxis to the drug was observed at the end of the treatment. This diminished drug response was more pronounced in the diurnal measurements of IOP on the same day. Similar phenomena have been described after treatment with adrenergic substances such as salbutamol and epinephrine (Paterson and Paterson, 1971, 1972; Langham, 1974; Langham and Diggs, 1974; Langham, 1975).

Our study seems to justify further investigation to ascertain whether local treatment with atenolol has a place in the treatment of glaucoma.

We thank Miss Ulla Andersson for technical assistance. The study was supported by grants from the Swedish Society of Medical Sciences and the Medical Faculty of Lund University. Atenolol was kindly supplied by ICI-Pharma, Gothenburg, Sweden.

\section{References}

Barret, A. M., Carter, J., Fitzgerald, J. D., Hull, R., and Le Count, D. (1973). A new type of cardioselective adrenoceptive blocking drug. British Journal of Pharmaco$\log y, 48,18$.

Bietti, G. (1972). Recent experimental, clinical and therapeutic research on the problems of intraocular pressure and glaucoma. American Journal of Ophthalmology, 73, 475-500.

Bonomi, L., and Steindler, P. (1975). Effect of pindolol on intraocular pressure. British Journal of Ophthalmology, 59, 301-303.

Borthne, A. (1976). The treatment of glaucoma with propranolol (Inderal) a clinical trial. Acta Ophthalmologica, 54, 291-300.

Bucci, M. G. (1976). La somministrazione locale dell'ox- prenololo (beta-bloccante) nella terapia del glaucoma. Nota preliminare. Bolettino d'Oculistica, 54, 235-242.

Cocret, P., and Bonnet, R. (1960). L'esthésie cornéenne. La Clinique Ophthalmologique, 4, 3-27.

Coté, G., and Drance, S. (1968). The effect of propranolol on human intraocular pressure. Canadian Journal of Ophthalmology, 3, 207-212.

Elliot, M., Cullen, P., and Phillips, C. I. (1975). Ocular hypotensive effect of atenolol (Tenormin, ICI). A new beta-adrenergic blocker. British Journal of Ophthalmology, 59, 296-300.

Hagedorn, A., and Tjoa, S. T. (1974). Practolol in the control of intraocular tension. Lancet, 1, 20, 733.

Langham, M. (1974). The pharmacology of the adrenergic therapy of glaucoma. In International Glaucoma Symposium Albi, pp. 315-334. Edited by R. Etienne and G. D. Paterson. Cedex: France.

Langham, M. (1975). Adrenergic tachyphylaxis in animal and human eyes. Experimental Eye Research, 2, 174-175.

Langham, M., and Diggs, E. (1974). Adrenergic neurone presynaptic mechanisms in the development of tachyphylaxis to norepinephrine and epinephrine. ARVO Meeting, Sarasota Flo., April.

Musini, A., Fabbri, B., Bergamaschi, M., Mandelli, V., and Shanks. R. G. (1971). Comparison of the effect of propranolol, lignocaine and other drugs on normal and raised intraocular pressure in man. American Journal of Ophthalmology, 72, 773-781.

Öhrström, A. (1973). Clinical experience with propranolol in the treatment of glaucoma. Acta Ophthalmologica, 51, 639-644.

Pandolfi, M., and Öhrström, A. (1974). Treatment of ocular hypertension with oral beta-adrenergic blocking agents. Acta Ophthalmologica, 52, 464-467.

Paterson, G. D., and Paterson, G. (1971). A comparison of the ocular hypotensive actions of salbutamol and adrenaline in chronic simple glaucoma. Postgraduate Medical Journal, 47, 122-124.

Paterson, G. D., and Paterson, G. (1972). Drug therapy of glaucoma. British Journal of Ophthalmology, 56, 288-294.

Phillips, C. I., Howitt, G., and Rowlands, D. J. (1967). Propranolol as ocular hypotensive agent. British Journal of Ophthalmology, 51, 222-226.

Sharaf, E., Haroun, E., Ishaac, Z., El Shewy, T., and Nassef, A. (1974). The effect of some beta-adrenergic blockers on human intraocular pressure. Experimental Eye Research, 19, 223-225.

Vale, J., Gibbs, A. C., and Phillips, C. I. (1972). Topical propranolol and ocular tension in the human. British Journal of Ophthalmology, 56, 770-775.

Vale, J., and Phillips, C. I. (1970). Effect of DL- and Dpropranolol on ocular tension in rabbits and patients. Experimental Eye Research, 9, 82-90.

Vale, J., and Phillips, C. I. (1973). Practolol (Eraldin) eye drops as an ocular hypotensive agent. British Journal of Ophthalmology, 57, 210-214.

Wettrell, K., and Pandolfi, M. (1975). Effect of oral administration of various beta-blocking agents on the intraocular pressure in healthy volunteers. Experimental Eye Research, 21, 451-456.

Wettrell, K., and Pandolfi, M. (1976). Early dose response analysis of ocular hypotensive effects of propranolol in patients with ocular hypertension. British Journal of Ophthalmology, 60, 680-683.

Wettrell, K., Wilke, K., and Pandolfi, M. (1977). Effect of beta-adrenergic agonists and antagonists on repeated tonometry and episcleral venous pressure. Experimental Eye Research (In press.) 